Joint Meeting of the Australian Society of Anaesthetists and the Canadian

Anaesthetists' Sociely

October 12-16, 1991

Brisbane, Australia

For Information:

Dr. J.P. Bradley

Conference Chairman

P.O. Box 1280

Milion, Queensland

Australia 4064

Telephone: (617) 369-0477

Fax: (617) 369-1512

7th Asean Congress of Anaesthesiologists November 6-9. 1991

Kuala Lumpur, Malaysia

For Information:

Dr. S.W. Lim

Pantai Medical Centre

59100 Kuala Lumpur

Malaysia
Finh International Symposium of Anesthesia and Intensive Care November 13-15, 1991

Dead Sea, Israel

For Information:

Dr. G. Geirman

Division of Anesthesiology

Sovoka Medical Centre

Beer-Sheva 84101

Israel

\section{Anesthesia History Association:}

Third International Symposium

March 27-31, 1992

Atlanta, Georgia

For Information

Dr. John E. Steinhouse

Symposium Committee Chairman

Emory Clinic

1365 Clifton Road

Atlanta, Georgia 30322 16th International Congress of the Israel Society of Anesthesiologists

June 9-12, 1992

Haifa, Israel

For Information:

Secretariat

Anesthesiologists

P.O. Box 50006

61500 Tel Aviv

Israel

Telephone: 9723654571

Fax: 9723655674

Telex: 341171 KENS IL

10th World Congress of Anaesthesiologists June 12-19, 1992

The Hague, The Netherlands

For Information:

Secretariat

10th World Congress of Anaesthesiologists

c/o Holland Organizing Centre

16 Lange Voorhout

2514 EE The Hague

The Netherlands

Telephone: $(+31.70) 365.78 .50$

Fax: $(+31.70) 361.48 .46$

\title{
G.P. ANAESTHETIST REQUIRED \\ LEAMINGTON DISTRICT MEMORIAL HOSPITAL
}

Due to the retirement of the incumbents from active practice, two General Practitioner Anaesthetists are required immediately for a 157 bed accredited Acute Care Hospital serving a catchment population of 45,000.

Leamington is situated on the shores of Lake Erie, 45 minutes from two major Metropolitan Centres; Windsor and Detroit. There are numerous recreational facilities, progressive schools and churches of all denominations. The Hospital is well equipped with current technology and has a full staff of consulting specialists

Please call collect or write for further information to the following:

Ms. Kathy Regan, Acting Executive Director

Leamington District Memorial Hospilal

194 Talbot Street West, Leamington, Ontario N8H 1N9

Phone (519) 322-2501

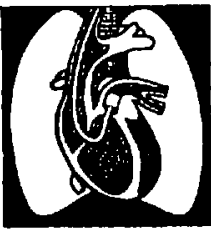

AUGUST 30 - SEPTEMBER 2, 1991

LA COSTA SPA AND RESORT, CARLSBAD, CALIFORNIA

SECOND INTERNATIONAL

\section{Cardiac, Thoracic, and Vascular Anesthesia Update and Review}

Accredited by The Mount Sinai School of Medicine in cooperation with

Journal of Cardiothoracic and Vascular Anesthesia (JCTVA) and the

World Association of Cardiac, Thoracic, and Vascular Anesthesia

FACULTY:

Jonathan L. Benumof, M.D., Joel A. Kaplan, M.D., John Murkin, M.D.

Michael F. Roizen, M.D., George Silvay, M.D., PH.D., Gerald D. Buckberg, M.D.

(JCTVA Honored Lecturer)

For further Anita V. Guffin, M.M.S., Program Coordinator, CT-Anes

information:

P.O. Box 287, Port Chester, NY 10573

(212) 2418392 